\title{
The CUT's Experience during the Workers' Party Governments in Brazil (2003-2016) ${ }^{1}$
}

\author{
José Dari Krein, University of Campinas, Brazil \\ Hugo Dias, University of Campinas, Brazil
}

\begin{abstract}
This paper looks at the development of the Unified Workers' Central of Brazil (CUT) during the four consecutive Workers' Party (PT) governments, first under Luiz Inácio Lula da Silva and later under Dilma Rousseff. The analysis draws on various aspects of the power resources approach, but focuses specifically on institutional power. The government found it politically difficult to implement a left-wing programme, due to the complex nature of the ruling coalition and its conservative opposition in the broader context of neo-liberal hegemony and financial globalisation. By continuing to establish dialogue with social movements, the PT governments stimulated forms of social participation in developing public policies, reinforcing existing institutions and creating new ones. By using its institutional power, the CUT was able to strengthen its participation in public institutions. There were hardly any substantial debates on labour or employment conducted without the CUT's participation. On the other hand, the privileged spaces in the labour arena did not achieve structural changes capable of redefining the country's development model and the standard of work regulation.
\end{abstract}

\section{KEYWORDS}

Brazil; CUT; trade unions; power resources; institutional power; PT governments

\section{Introduction}

This paper looks at the development of the Unified Workers' Central of Brazil (CUT) ${ }^{2}$ during the four consecutive Workers' Party (P'T) governments, from 2003 to 2016, first under Luiz Inácio Lula da Silva and later under Dilma Rousseff. The CUT is currently the main trade union federation in Brazil and Latin America, and the fifth largest in the world. In 2016 it had 3800 affiliates with a membership of 7.8 million unionised workers out of a workforce of 24 million (CUT, 2016). Internationally, the CUT plays a prominent role in regional organisations such as the Trade Union Confederation of the Americas (TUCA), in global unions through its confederations, and in the International Trade Union Confederation (ITUC), whose current president was formerly president of the CUT.

\footnotetext{
1 We would like to thank Patrícia Rocha Lemos and Ana Paula Colombi for their contribution to this article, as well as the Friedrich Ebert Stiftung Brazil and Achim Wachendorfer for their helpful input.

${ }^{2}$ A list of abbreviations and acronyms appears at the end of this article for the reader's convenience.
} 
In theoretical and methodological terms, the authors use the categories of the power resources approach to analyse the evolution of the CUT during the PT governments. These categories structural, associational, institutional and societal - are described in detail in the Introduction to this Special Issue (see also Wright, 2000; Silver, 2003). While the analysis will consider the interplay between the four different power resources, the main focus will be on changes that occurred specifically in institutional power. As "a secondary form of power", institutional power is the result of previous struggles and negotiation processes based on structural power and associational power. In the Brazilian case, neo-liberal policies had been introduced during the 1990s, and these had a negative impact on workers. The CUT's strategy for political change was based on being part of a larger political camp. Although the CUT had lost some of its structural and associational power due to the economic crisis, this strategy ultimately led to the strengthening of its associational and societal power through its link to the PT (associational power) and to wider social movements (societal power).

The 2002 election of Lula as Brazilian president meant a political break with the past. The PT established itself as a political party that brought together an expressive part of the different urban, rural, social, trade union and environmental movements, expressing the demands of these social groups. But the PT entered the government through a broad ideological political coalition that brought together traditional sectors of politics and business segments.

The political approach of the PT governments was designed to stimulate broad participation in elaborating public policies, reinforcing existing institutions and creating new ones. The intention was to seek support from social actors for the redefinition of policies that have historically been central in the trajectory of the PT. Such was also the demand of the organised social movements themselves, including trade unions and in particular the CUT, which had, since the 1990s, developed a strategy of occupying institutional spaces and negotiating issues affecting workers' lives.

However, the political difficulty of implementing a more left-wing programme soon became evident, due to the complex nature of the government coalition and its conservative opposition in the broader context of neo-liberal hegemony and financial globalisation. Therefore, with the prospect of continuing to establish dialogue with different social movements, the PT governments adopted the modus operandi of solving differences through social dialogue and searching for consensuses in institutional spaces.

The election of Lula also generated high hopes among trade unionists that the focus would now be on creating jobs and promoting social inclusion based on a new development model for the country. The authors identified contradictory elements during this period. The nature of the relations between the CUT and the PT government changed during this period of almost a decade and a half, with distinct impacts on power resources and trade union strategy. The CUT had to find ways of handling its dual role of representing the workers' interests and partaking in government, while facing criticism from conservative segments of society. It had to mediate between the "logic of membership" and the "logic of influence" (Schmitter and Streeck, 1999). That is, using institutions for one's own ends while retaining political autonomy became crucial. Hence, the CUT lost some ground among trade unions and society in part due to its adoption of a more moderate political approach (Boito, Galvão and Marcelino, 2015).

Factors such as the implementation of new social and economic policies, the close relationship between the CUT and the PT, and the progress achieved in collective bargaining and unionisation strengthened the CUT's structural, associational and institutional power. With regard to its 
institutional power, the CUT was able to strengthen its participation in relevant organisations and public institutions, most notably the Brazilian Economic and Social Development Council (CDES), whose mission was to define a development model for the country, and the tripartite National Labour Forum (FNT).

Our main argument is that the significant advance of participation spaces was the result of the rise of the PT to power, which then sought consensual changes with the main social actors, especially in the productive sector (that is, the economy), but that the result was contradictory with regard to labour. On the one hand, the social dialogue processes have provided better living conditions for the population at the bottom of the social pyramid, especially from the point of view of employment, social protection and income. On the other hand, the privileged spaces in the labour arena did not achieve structural changes capable of redefining the country's development model and the standard of work regulation. Advances were only made when there was consensus between capital and labour. After the impeachment of President Rousseff, these spaces were reconfigured in terms of composition and/or emptied from the point of view of content, especially those that are enshrined in the Federal Constitution.

The study builds on previous research conducted by the authors (Krein, Dias and Colombi, 2015; Krein and Dias, 2017). It also includes new quantitative data, documents produced by union centrals and recent literature. Formally the text is divided into six parts, besides the introduction: a brief historical contextualisation; the period from Lula's inauguration as president in 2003 until the political crisis of 2005; Lula's second mandate between 2006 and 2010; Dilma Rousseff's first mandate from 2011 to 2014; the political crisis that led to the impeachment process in 2016; and closing remarks.

\section{History and Context: The Contradictions of Brazilian Corporatism}

Since the 1930s, the Brazilian trade union movement has been controlled by the state through a corporatist system. It has several elements. First, the principle of exclusivity only allows one local trade union in each municipality and bans factory-based trade unions. Second, it is characterised by a vertically organised system - confederation at national level, federation at state level, and trade unions for each economic sector and each profession; any kind of horizontal organisation was formally banned until 1986 and only officially legalised in 2008. Third, negotiation of collective bargaining agreements takes place between a trade union and a corresponding employers' association. Fourth, a trade union organisation has to be legally recognised to be able to use its prerogative rights. Fifth, until 2017 there was guaranteed state funding via compulsory contributions, namely a trade union tax and a contribution to the confederation, ${ }^{3}$ as well as other duties linked to collective bargaining and membership fees. Lastly, decision-making power lies with local trade unions.

This structure is marked by a high degree of ambivalence and flexibility. On the one hand, the state safeguards and controls the trade union system, which contributed to the founding of innumerable trade unions - more than 22000 as of 2016, many of them without any representativeness, as the founding of a trade union depends merely on the fulfilment of legal

${ }^{3}$ The Labour Law Reform of 2017 suffocated the two main sources of union funding by eliminating the trade union tax and restricting the collection of fees to union affiliates only. 
requirements and not on the desire of the workers to be represented. On the other hand, Brazilian legislation grants a series of rights and prerogatives to trade unions in order to ensure their functioning. This includes certain protection rights for trade union leaders, guaranteed state funding, the (limited) right to strike, and the right to collective bargaining as a way of defining standards. Brazilian law further allows different trade union federations to coexist and to compete for local trade union affiliation. Therefore, the representation system is characterised by unicity at the base and pluralism at the top.

Looking back in history, it is possible to find examples of diverging applications of the same laws, depending on the political regime in power. Between 1930 and 1980, the period in which the country was industrialised, Brazil experienced thirty-five years of authoritarian rule and fifteen years of democracy marked by a high level of instability. The authoritarian governments tried to intervene in order to impede unions from exercising their right to collective representation of the workers' interests. During moments of democratisation, several official bodies played a decisive role in coordinating and planning activities and struggles in favour of single professional categories as well as in favour of the general workers' interests in society. Between 1950 and 1964, the year of the military coup, and towards the end of the authoritarian regime in 1985, it was common practise among workers to establish horizontal structures of representation outside of the official structure.

Despite a legal ban, the CUT was founded in 1983 amid the ongoing struggle for democracy in a country under military rule. It represents the "New Trade Unionism" that was and remains critical of the existing state-controlled trade union structures and is the result of the renewed relevance of the workers' movement at the end of the 1970s. This movement has its roots within the more modern segments of the working class who believe in a new conception of trade unions grounded on conventions of the International Labour Organization (ILO), such as freedom of association, and on more class-based and combative activities.

Even with the CUT's autonomy and the fact that it has affiliates from different left-wing political parties, the CUT and the PT share many common features, starting with the origin of both entities. The PT was founded in 1979 during the military regime, after the adoption of the law granting political amnesty. Its support base is very similar to the CUT's, bringing together organised left-wing groups, militants of the left-wing Christian liberation theology movement, intellectuals and trade unionists. Its relationship with the CUT is historically close, similar to several workers' movements across Europe. Luiz Inácio Lula da Silva, a well-known trade unionist, was the first president of the Workers' Party.

The CUT gained pace within society by combining activities for economic improvements campaigning for wage increases and for better working conditions - with the political struggle against the authoritarian regime and for democracy in Brazil. The latter involved intense striking, which proved to be a decisive instrument for a number of activities:

a) reorganising trade unions by electing more active leaders who promoted democratisation;

b) establishing new vertical structures for each industry, and for the CUT itself as a trade union federation;

c) consolidating collective bargaining;

d) giving trade union leaders the stage to gain a national reputation, including the future president Lula da Silva; and

e) legitimising trade unions, which gained the reputation of being trustworthy organisations in 
Brazilian society during the 1980s.

Two other trade union centres were also founded during this time - the General Workers' Trade Union Federation (CGT) in 1986, ${ }^{4}$ and the Union Force (FS) in 1991. ${ }^{5}$

The 1990s had a negative impact on workers. Neo-liberal policies aimed at economic liberalisation, stabilising the currency and restructuring the productive sector caused a large increase in unemployment and informal employment. During this period, the CUT was weakened, mainly in terms of associational power (loss of membership) and structural power (unemployment and loss of rights). However, it adopted new campaign strategies, which focused more on: collective bargaining in the different economic sectors; activities at institutional level by formulating public policies and regulating labour relations; widening its agenda by addressing new issues in order to attract new segments of society; networking with other social movements in the fight against neo-liberal politics; and promoting positive political change, which would come through the election of Lula as Brazilian president.

Regarding participation in institutions, the CUT moved from a contentious position that was common practice in the previous decade to adopt a strategy of "propositional resistance and dispute of hegemony in society", as the union central stated in its strategy documents at the time. CUT started participating in a diversity of institutional spaces enshrined in the Federal Constitution of 1988. This included playing a role in Councils of health, education, management of public resources of workers and public banks, among others. It also took part in newly created spaces, such as the Sectoral Chambers, meso-corporative institutions designed to formulate solutions to face the economic crisis of 1990-1992. According to a survey by Pochmann, Mendonça and Barreto (1998), by that time the trade union movement was present in more than forty spaces for definition of public policies. In the second half of the 1990s, the spaces of concertation were narrowed because the Federal Government of that time provided less funding for them. Even so, trade unions continued to invest energy in expanding their institutional participation by taking up space in Parliament and in the instances of participation guaranteed by the Constitution.

The CUT's strategy for political change was based on being part of a larger political camp. Although the CUT had lost some of its structural and associational power due to neo-liberal reform politics and economic crises, this strategy ultimately led to the strengthening of its associational and societal power through its links to the PT and to wider social movements respectively.

\section{3-2006: From Lula's Inauguration as President until the Political Crisis}

Lula's election victory in October 2002 gave rise to hopes among most trade unionists that the neoliberal policies of the 1990s could be reversed. However, because there was an economic crisis, the start of this government's tenure was conservative in many aspects, mainly regarding its economic

4. The CGT was established as a counterpart to the CUT and mainly aimed at defending the official trade union structure. Its affiliates range from traditional trade unions without links to political parties to the trade unions of the communist parties.

${ }^{5}$ Mounting tensions between the communist groups and more pragmatic approaches led to a split in the CGT. In 1990, the main communist tendency joined the CUT, while other groups established the FS in 1991. The FS defended an outcome-oriented trade union strategy, mainly concentrated within the private sector. 
policies and the agenda for debate in Parliament, such as the reform of the social security system for public sector employees. At the same time, a range of policies against poverty were implemented, such as the programme Fome Zero (Zero Hunger).

During this period, the CUT experienced an apparent paradox. On the one hand, due to its historical link to the political camp that supported Lula, it defended the government against attacks from conservative forces and criticism from the left, even though the CUT itself did not fully agree with the ongoing reforms and economic policies. It was precisely this lack of a clear position that caused two groups - CSP/CONLUTAS and the Intersindical ${ }^{6}$ - to leave the CUT. They were more to the political left and demanded a more critical attitude towards the government. On the other hand, the CUT managed to increase its institutional participation in the state through its membership of several councils and forums that defined and implemented public policies in Brazil (Araújo and Oliveira, 2011: 86).

Due to the complex nature of the government coalition and the difficulty in implementing structural changes, Lula's administration invested in the creation of negotiation spaces in the central themes of PT's historical agenda. Mechanisms of social participation were expanded and organised society was invited to participate. Although not all of the general concerns of a significant part of society were vocalised, public policies in favour of land and rural reform, hunger eradication and groups in Brazilian society who faced discrimination - such as women, young people, the LGBT community and people of colour - found their way onto the political agenda. Strong opposition from more conservative sectors of national political life was a constant and the trade union movement, especially the CUT because of its proximity to the government, decided to participate intensely, being directly involved in the implementation of these polices. This further contributed to the strengthening of its institutional power.

More and more trade unionists were also voted into Parliament. During 2003-2007, 69 out of 513 MPs were trade unionists in leadership roles in their organisations. ${ }^{7}$ Networking with other social movements and cooperating with other trade union federations were decisive for the CUT's societal power. The CUT is part of the Confederation of Social Movements (CMS) founded in 2003, which has among its members some of the main trade union organisations in the country, student associations, women's associations, black civil rights organisations and land reform movements, among others.

The economic recovery from 2004 onwards, which was initially fuelled by the commodity boom and later by a strong domestic market, came hand in hand with a political crisis in 2005. Facing attempts by the right to overthrow Lula's presidency, the government approached trade unions and social movements for support. Following negotiations with the trade union federations, policies were adopted that helped to pave the way for socially inclusive economic growth. These policies included an increase in the minimum wage, an increase in social benefits (the Bolsa Familia programme), and

${ }^{6}$ These two groups later split up into two different organisations. Both together made up 10 per cent of CUT's affiliates. However, these organisations do not fulfil the legal criteria for official recognition as trade union centrals.

${ }^{7}$ More than twenty parties are represented in the Federal Parliament. Therefore, the government's success in implementing its agenda depended heavily on its popularity and its ability to create alliances. This is even more the case as no left party, including the Workers' Party, ever got more than 20 per cent of the mandates in Parliament. 
the creation of consigned credit schemes which facilitated workers' access to credit (Baltar and Leone, 2016). These policy changes help explain the beginning of a dynamic of economic growth with social inclusion which characterised the PT governments. For instance, real wage increases through collective bargaining were obtained in the majority of professional categories from 2004 onwards (DIEESE, 2015a). That and the increase of the minimum wage contributed to a reduction in income disparities and to an increase in purchasing power. Moreover, there was a significant reduction in unemployment and a growth in formal employment, which substantially increased the number of people protected by social security.

However, from labour's point of view, the results were contradictory. Changes in economic policy were not achieved and a conservative microeconomic agenda remained a factor of tension between the trade union movement and the government. That is, changes only came about when there was consensus among social actors (Colombi, 2018).

In 2003, government created two important institutions in which trade unions had significant participation. The first was the Economic and Social Development Council, directly linked to the Presidency, with ministry status; its mission was to define a development model for the country. The second was the tripartite National Labour Forum that debated the reform of the trade union system and labour law. Although the CDES did not implement significant changes, it succeeded in bringing the union centrals closer to each other and to the government. However, the FNT was not able to reach consensus on the reforms. After more than three thousand hours of negotiations between trade unions and government, it was not possible to bring about a reform, as there was growing dissent; the proposal for a new system of trade union organisation and collective bargaining was not approved by Parliament.

The 2003-2005 period was, therefore, a period that started with tensions and affiliates leaving the CUT, but also one that enhanced the CUT's participation in the process of policy formulation with positive results for workers and the trade union movement under the hegemony of the CUT. Consequently, this period was marked by a strengthening of the federation's structural, associational and societal power, as well as institutional power resulting from the establishment of new structures for participation.

\section{6-2010: The Height of Lulaism ${ }^{8}$}

Between 2006 and 2010, the PT government changed its approach to development and the state. It took on a more prominent role in the economy by restructuring public services, requesting new tenders, making public employment more attractive, strengthening state-owned companies, and promoting socially inclusive economic growth. It was at this time that the main trade union federations joined the support base that was sustaining the government, with the exception of a few more left-wing groups. The institutional structures were maintained and policies to counteract the effects of the crisis were negotiated together.

Faced with the global economic crisis in 2008, the government adopted policies to spur domestic demand via negotiations with the trade union federations. This led to economic growth. Together with policies to strengthen social inclusion through private consumption, this growth

8 "Lulaism" is a concept developed by Singer (2012) in order to show that Lula was gaining support among the non-organised segments of society due to his social policies. 
brought very positive results - a decrease in unemployment and informal labour; increased income for workers, especially the less-qualified; a reduction in salary discrepancies; and an increase of the age at which young people start to work (Krein and Manzano, 2014).

During the second term of office, the number of trade unionist MPs decreased from 69 to 55, but unionists continued to have an important voice in Parliament and occupied high offices in public bodies (D'Araujo, 2009). For example, the Ministry of Labour and Employment was handed over to the Union Force, the second-largest trade union central. This social dialogue and the participation of trade union leaders in public bodies strengthened the direct relationship between the government and the trade union movement.

From 2006, the CUT's strategy was based on two pillars: strengthening democracy and valorisation of work. Since the end of 2004, the CUT has organised the yearly Working-Class Marches, together with other trade union federations. While the first three marches mainly called for an increase in the minimum wage, the 2008 march put forward a new agenda. Two important documents were written: Workers' Agenda for Development: With Income Distribution and Valorisation of Work (Centrais Sindicais, 2007) and Agenda for a National Development Project: With Sovereignty, Democracy and Valorisation of Work (Centrais Sindicais, 2010). Both documents demanded that the government take a more active role in promoting development and emphasised the benefit of an increase in the minimum wage and the creation of jobs for economic growth and development. During the 2008 economic crisis the CUT maintained its strategy and supported the countercyclical policies adopted by the government, such as tax cuts in order to promote investments and consumer spending and to prevent mass redundancies.

During this period, the CUT was an active member of the Labour Relations Council ${ }^{9}$ (CRT) and the Deliberative Council of the Workers' Assistance Fund (CODEFAT) through which it participated in debates on labour and employment policies. The CUT was further involved in implementing policies for particularly vulnerable groups of society such as women, young people, the LGBT community and people of colour.

Several elements contributed to a strengthening of the trade union movement's resources of power. First, trade unions federations worked on improving networking and joint mobilisation activities such as the Working-Class Marches. Second, there was an increase in the absolute number of members, but a loss in density, as more jobs were created than workers were unionised (Alcantara e Silva, 2018). Third, the bill on official recognition of the trade union federations in 2008 was a positive factor. The CUT made concessions during those negotiations regarding its view of trade unionism, mainly concerning the compulsory contributions and the principle of exclusivity of representation. ${ }^{10}$

Legal recognition of trade union federations contributed to a strengthening of the trade union federations' associational and institutional power, even though it brought three undesired

9 The CRT was created in 2010, with a tripartite composition, after the demise of the National Labour Forum as part of the new legislation that recognised trade union federations.

${ }^{10}$ By law the trade union federations need to fulfil some criteria regarding representativeness to be officially recognised, such as distribution in the regions and within economic sectors and a representation of at least 7 per cent of all trade union members. Official recognition meant that 10 per cent of the trade union tax revenue paid by every Brazilian worker was passed to the trade union federations. In 2008, this corresponded to approximately $\mathrm{R} \$ 38$ million, and in 2014 to nearly $\mathrm{R} \$ 80$ million of which the CUT receives one-third. [R $\$$ is the currency abbreviation for the Brazilian Real.] 
consequences. First, an increase in the fragmentation of the trade union movement was experienced on all levels as new trade union organisations were founded. The number of trade union federations rose to twelve, of which six are officially recognised. ${ }^{11}$ Second, there emerged an inability to agree on a reform of the trade union structure which would consolidate the fragmentation of the trade union system, where many entities exist but with little representativeness. Third, the emergence of a "trade union market", where the trade union federations competed for new members as every new affiliate means an increase in revenue, hampered reform. This reinforced the contradictory trade union structure in Brazil.

In short, the period between 2006 and 2010 was the height of Lulaism and of the relationship between the PT government and the trade union movement. After the political crisis of 2005, and in the midst of intense political debate in Brazilian society, the government sought to deepen its relationship with trade unionism, opening more space, often informal, to the trade union centrals under the leadership of the CUT. The result was that all formally recognised union centrals supported the PT's candidature in the 2010 election.

The balance of this period was also contradictory. Structural power increased, due to the growth in formal employment and in income, which were reflected in better living conditions for a large part of the population. At the same time, however, the trade union movement did not expand its associational power and lost legitimacy in society. The main reason was the steady withdrawal of the middle-wage sectors from the base of the PT. Regarding institutional power, there were no substantial changes to the model of development and labour relations. The legal recognition of trade union federations was the only part of the trade union reform that "survived", generating mixed consequences which are discussed below.

\section{1-2014: The Government of Dilma Rousseff}

The previous period was marked by decisive progress in terms of restructuring the labour market. Thus, Lula's candidate, Dilma Rousseff, was elected president despite furious rhetoric against her among the middle and upper-income classes. They were opposed to policies that promoted social inclusion, to corruption, to their loss of social status, and to public services incapable of attending to the growing masses of people consuming, travelling and using those services.

During this period, the economy began to slow. While the economy had grown 7.6 per cent in 2010, by 2014 the growth rate was zero. There were several causes of the economic downturn. These included the ongoing international crisis and the fact that the expansion of domestic consumption was nearing its limits. Also contributing to the situation was the government's inability to implement a development project, and several important initiatives not being successful either due to mistakes made during their implementation or to strong opposition from the economic elite of the country. A

${ }^{11}$ In 2007 the class-based Union Current left the CUT and founded the Brazilian Workers' Trade Union Federation (CTB), which later received official recognition. Today's officially recognised trade union centres are the CUT, the FS, the CTB, the General Workers' Union (UGT), the New Workers' Union Central (NCST) and the Central Brazilian Union (CSB). The ones not officially recognised are: the Central of Trade Unions and Popular Movements (CSP/CONLUTAS), the Brazilian Democratic Workers' Central (CBDT), the Unified Central of Public Servants of Brazil (CSPB), the Intersindical/Working-Class Central and Intersindical/Instrument of the Working-Class's Struggle. 
final contributor was incorrect interpretation of the current context and economic policy mistakes, especially concerning exchange rate policy. The economic problems were used by the big media corporations and opposition groups to wear down the government.

In spite of the economic slowdown, labour market indicators were still improving. Unemployment sank to its lowest level by the end of 2014 (4.8 per cent), less the half of what it was when the PT took over in 2003. Wages continued to grow above inflation thanks to an increase in the minimum wage and positive collective bargaining results. Even increases in variable pay, such as profit-sharing schemes, were achieved. This shows how efficiently the trade unions managed to increase workers' purchasing power, especially in low-income groups of society. The formal employment sector was also still growing. This improvement of indicators cannot be explained merely by the dynamic of the economy, but rather by other factors such as demographic change, higher household income, the state's policies of social inclusion and the fight against illegality.

During this period the relationship between Rousseff's government and the trade union movement started to show signs of wear. The number of trade unionist MPs again increased to 64, the majority belonging to the CUT. Some of the highest governmental offices were occupied by trade unionists during this government. The institutional structures for dialogue and cooperation still existed and meetings were held. However, the interaction between the social actors and the government became more intricate, which impeded the building of a consensus around a common agenda. At the same time, the difficulties the country was experiencing highlighted the different understanding of how the economic problems should be solved and of how social inclusion policies should be implemented.

The government attempted to adopt some ambitious measures, mainly in 2012 - namely reduction of interest rates, strengthening of public banks and exchange depreciation. The aim was to reduce profit from speculation and to stimulate productive investments. However, these actions led to growing discontent, especially in the financial market and among the big media corporations. Moreover, the poor quality of public services, the rise in inflation (albeit short) and investigations into corruption cases, mainly in the more developed regions of the country, contributed further to the discontent.

Policies to return to a development agenda were adopted unilaterally by the government. For example, the policy of tax incentives for companies, which weakened the social security system, was not negotiated with trade union centrals. At this time, the CUT, while belonging to the same political camp, started to criticise the government for its lack of dialogue and for its economic policy. Even though the government met some of the CUT demands, the dialogue between the CUT and the government became more strained, increasingly giving way to more explicit criticism.

With regard to labour regulations, the record of governmental policies shows that there are contradictory elements. Some measures increased protection (increases in minimum wage, the strengthening of domestic workers' rights and the promotion of gender equality), while others increased flexibility (social security reform). However, some demands made by the trade union federations were not taken into consideration, such as a reduction of working hours, the introduction of a mechanism preventing unjustified dismissals and a more inclusive social security system (Krein and Biavaschi, 2015).

The topic that was most visible was the one on easing labour law, including permission to subcontract workers and the prevalence of negotiated terms over legislation. This had been a demand of the private sector in the 1990s. The government, through the Labour Relations Council, 
tried to negotiate an agenda of flexibilisation. The CUT played an important role in preventing the passing of some of the demands of the private sector into law, dominating the resistance against legalising the indiscriminate subcontracting of workers. There was no major agreement, and institutional spaces, although they remained in place, were emptied. As the negotiation space narrowed, the relation of attrition deepened. In short, neither employers nor workers saw their agenda being taken up by the government.

Regarding the CUT's internal structure, progress was made in attracting segments of society that had hardly been represented before and in broadening its agenda. The debate about these topics had started in the 1990s. However, it was only in the first decade of the new millennium that the new issues were institutionalised within the CUT's organisational structure with the establishment of the Secretariat of Working Women (2003), the Secretariat of the Fight Against Racism (2009), the Secretariat of the Environment (2009) and the Secretariat of Young People (2009). As for gender equality, the 11th CUT congress in 2012 voted for equal representation of women and men at all leadership levels of the federation. Also worthy of mention is the establishment of the Agency for Solidary Development (1999), which promotes the management of companies by the workers themselves as well as alternative forms of work and income generation. In 2012, the CUT founded the Cooperation Institute. From being a mere beneficiary of international solidarity, the CUT started to develop a more systematic approach to international cooperation.

From 2013 onwards, important changes affected society and politics. Since 2008, there had been an increase in labour conflicts, in a context of greater difficulty in advancing the negotiations due to the slowdown in economic growth and higher inflation. Despite the growing number of strikes and other industrial action, the main mobilisations during the period were not carried out by trade unionism, even being challenged in some cases. Such challenges took place during the demonstrations of 2011 in the great works of the Growth Acceleration Programme (PAC), the demonstrations of June 2013, and in several strikes in 2014 (urban waste collection workers in Rio de Janeiro and bus drivers in Porto Alegre) (DIEESE, 2015b; Braga, 2017).

The demonstrations in June 2013 mobilised the masses, initially demanding a reduction of public transport rates and protesting against public spending for the 2014 World Cup. On the one hand, more and more people joined these protests, particularly young people who belonged neither to trade unions nor to political parties. There were progressive groups that pointed out the limits to the strategy of social inclusion by means of private consumption instead of by fully safeguarding citizenship rights. On the other hand, these protests were taken over by conservative groups, with the support of the big media corporations, that aimed at preserving the status quo for the middle and upper-income classes, as they benefited from inequality. They protested against social inclusion policies, such as the Bolsa Familia programme, the minimum wage and the affirmative action law with racial quotas at universities.

Some social movements, such as the Homeless Workers' Movement (MTST), gained strength during this period, but it was mainly the Right that benefited and that found a common enemy and scapegoat for the problems of society: they blamed the "reds". The CUT maintained its associational and institutional power, but this new situation put pressure on its structural and societal power. The trade union movement was not welcome at these protests. There are countless reports of aggression against bearers of the red flags of left-wing parties and the CUT. At the height of the protests in July, the trade union federations organised marches in order to bring their demands back to the country's agenda. The demonstrations were smaller in size than the counter-protests, but they drew attention 
to the workers' agenda. The CUT's lack of leadership in the 2013 protests seems to be reflected in the trustworthiness index, which fell to its lowest level in that year, even though it was a record year of strikes.

During this period the economic prospects became more difficult and the position of the trade union actors also more divided. In addition, the flexibilisation agenda was taken forcefully. For example, in the National Congress, of the fifty-five major legislative initiatives threatening workers' rights, thirty-two were submitted or resubmitted after 2013 (Krein et al., 2017). The CUT, despite a more worn relationship and a greater distance from the Rousseff government, nevertheless adopted as strategy the defence of its re-election with the objective of avoiding the return of the Right to power in the 2014 election.

\section{5: The Impeachment of Dilma Rousseff}

Notwithstanding a growing political polarisation and the strengthening of the Right, civil society organisations were mobilised in large numbers by campaigns, which the CUT participated in, to work for Rousseff's re-election in 2014. The growing polarisation also reflected itself within the union system, where divisions were increasingly visible. While in 2010 all the official trade union federations supported Rousseff's election, by 2014 it was only the CUT that did so. The other trade union federations were incapable of agreeing on one candidate due to internal divisions, and the FS, the second largest federation, predominantly supported the opposition.

This was the moment when the economic indicators started to deteriorate, exacerbated by the government's change of course towards a conservative austerity agenda which included restrictions to access to unemployment benefits and to minimum wage bonus schemes and a sharp rise in prices, particularly of petrol and energy. Moreover, and as a consequence of growing polarisation, the conservative forces clearly won the Congress elections in 2014. A liberal agenda was introduced and any attempt by the government to pass legislation was blocked. Growing unemployment, inflation, austerity measures, the weakening of its grassroots support base, the tactic of blocking government policies, and a strengthening of the Right further exacerbated the economic, political and social crisis and played an important role in the lead-up to the impeachment process. Moreover, the Right is highly represented in Brazilian public institutions - especially in the judiciary - and the media landscape is dominated by five big corporations that strongly supported the coup.

Seeing that support for the institutional coup was growing, the government assumed a conservative and liberal agenda. This included privatisation of state-owned companies, weakening of public banks, cuts in social benefits with freezing of public spending for twenty years, restrictions on workers' rights, permission to sell land to foreign companies, and increasingly opening the market to international companies for oil production.

During the impeachment process, institutional spaces of negotiation almost disappeared as the dispute over the general course of the country intensified. A considerable number of trade union organisations joined the fight for democracy, but with the exception of the CUT and the CTB all of the trade union federations had to deal with internal divisions. Several other social and more leftwing trade union organisations joined the movement, which did not, however, support the Workers' Party. Thus, the fight for democracy brought the CUT and social movements closer together again, which temporarily strengthened the CUT's societal power. At the same time, the CUT lost some 
support amongst its affiliates, especially among more qualified workers with higher incomes. This latter group was more inclined to support the institutional coup, hoping that political change would end the economic crisis that has affected Brazil since the end of 2014 - a hope fuelled by the press, but never fulfilled.

The CUT was one of the main actors in the coordination of the demonstrations against the institutional coup and decisive in organising the protests. The CUT participated in the Brazilian Popular Front movement and in the People Without Fear movement, two alliances that played an important role in the protests in defence of democracy and social rights in 2015 and 2016. Most notably, in 2015 important protests were organised by the trade union movement against a draft bill that aimed to fully liberalise the subcontracting of workers. Strong mobilisations postponed its approval to 2017. Over weeks and months, demonstrations in defence of democracy and social rights increased significantly, though they still did not bring together as many people as the protests organised by the Right.

After the illegitimate government took power on 12 May 2016, it initially tried to seek support from part of the trade union movement. Soon, however, it aborted any negotiation with the unions, assuming in full the bosses' agenda in the economic field, social protection and labour rights. The trade union federations split into two blocks: four of them (FS, NCST, CSB and UGT) decided to negotiate with the government, whereas the other two (CUT and CTB) together with another two other left-wing (and not officially recognised) trade union federations decided not to recognise the new government. The Economic and Social Development Council itself was redesigned, with the participation of workers reduced to less than 5 per cent of its members. The CUT and other trade union centrists critical of the coup were expelled from the CDES.

Within this context, the CUT assumed a position of resistance against the government's plans to reform labour law and the social security system. This resistance occurs in a difficult context. On the one hand, CUT's social and associative power has been weakened, because it cannot mobilise part of its base in defence of democracy and social rights. On the other hand, it also loses institutional power because its position of non-recognition of the institutional coup means that it can no longer be the interlocutor of labour demands with the new government. Thus it has been isolated by the new block in power.

\section{Closing Remarks}

Over the last decade, the CUT has contributed to the shaping of alternative governmental politics. The election of a trade union leader as Brazilian president brought both advantages and disadvantages. The CUT became an indirect part of the coalition in power. This was a complex relationship, with trade unionists taking up political posts and the CUT supporting them publicly. The strong link with the government also meant that, at least during the times in which the government was popular (the greatest part of the period analysed), the CUT grew stronger. However, it also meant that its image suffered during moments of crisis, as in 2005 and after the protests in June 2013. Although the proximity between PT and CUT remained very strong, the CUT always sought to maintain its autonomy by putting pressure on the party to defend its demands in the National Congress, by organising demonstrations and making demands to improve workers' living conditions. 
The CUT's associational and structural power increased during the four governments, due to the period of unprecedented socially inclusive economic growth. This was apparent in several ways. First, the CUT continued to be the main union federation (36 per cent in 2015), despite other trade union federations such as UGT and CTB gaining relative importance. Second, legislation was passed that officially recognised the union federations and guaranteed their funding. Third, the membership of trade unions increased by 4.5 million, although the number of new jobs created increased by 21 million (Alcantara e Silva, 2018). Fourth, the unions were able to organise strikes, which rose in numbers until 2016 (DIEESE, 2015b, 2017). Fifth, real wage increases were achieved in collective bargaining. Sixth, the establishment of the new Secretariats for women, youth and anti-racism shows that new topics were embraced and considered a priority.

With regard to its institutional power, the CUT was able to strengthen and to increase its participation in public institutions. It took part in more than 140 forums where public policies were debated and formulated. Furthermore, there were hardly any substantial debates on labour or employment conducted without the CUT's participation. On the other hand, the privileged spaces in the labour arena did not achieve structural changes capable of redefining the country's development model and the standard of work regulation. Advances were only made when there was a consensus between capital and labour. The most substantive result is the fact that there was no deconstruction of workers' rights as sought by the neo-liberal project.

In PT governments, the institutional power of workers was strengthened, despite the contradictions and limits of a modus operandi of institutional consensus. After the impeachment of President Rousseff, formal institutionality was maintained, but these spaces were either reconfigured in terms of composition - applying the principle of selectivity, including supporters and excluding critics -or emptied of content, especially those that are enshrined in the Federal Constitution.

The CUT's experience reveals how essential it is, despite progress in institutional terms, not to neglect other power resources. Institutional power, even if backed by legislation, can only be enacted if there is commitment from other social actors, particularly the state. The influence that trade unionism can have in these arrangements depends heavily on the ability to draw from primary sources of power - structural and associational. The closeness between the CUT and the PT governments at first gave the CUT more institutional power, but also made it vulnerable to attrition with the fall of popularity of the Rousseff government and with the mobilisations against the impeachment. Currently there are several challenges - regaining representativeness, mobilising its traditional base of support and building alliances. The CUT must improve its framing capacity in order to strengthen its position in the political debate on the country's direction in a context of labour market destructuring and of a strong offensive against workers (Melleiro and Steinhilber, 2016; see also Schmalz, Ludwig and Webster, this issue).

\section{REFERENCES}

Alcantara e Silva. P. (2018) Filiação sindical dos empregados formais no Brasil. Dissertação de Mestrado. Instituto de Economia, Unicamp.

Araújo, A. and R.V. de Oliveira (2011) El sindicalismo en la era de Lula: entre paradojas y nuevas perspectivas. Trabajo, 5(2): 83-112.

Baltar, P. and E. Leone (2016) Crescimento com inclusão social e mercado de trabalho de baixos salários. Anais $1^{\circ}$ Congreso Internacional de Relaciones del Trabajo, Sevillha, 26-29 January 2016. 
Boito Jr., A., A. Galvão and P. Marcelino (2015) La nouvelle phase du syndicalisme brésilien. Cahiers des Amériques Latines, 80: 147-67.

Braga, R. (2017) The End of Lulism and the Palace Coup in Brazil. Global Dialogue, 7(4). http://isa-globaldialogue.net/the-end-of-lulism-and-the-palace-coup-in-brazil.

Centrais Sindicais (2007) Agenda dos trabalhadores pelo desenvolvimento [Workers' Agenda for Development with Income Distribution and Variations of Work]. http://library.fes.de/pdffiles/bueros/brasilien/04806.pdf (accessed 12 April 2017).

Centrais Sindicais (2010) Agenda para um Projeto Nacional de Desenvolvimento [Agenda for a National Development Project with Sovereignty, Democracy and Valorisation of Work]. www.sinaaejf.org.br/site/ arquivos/agenda_conclat_versao_2011.pdf (accessed 12 April 2017).

Central Única dos Trabalhadores (CUT) (2016) Breve Histórico. https://www.cut.org.br/conteudo/brevehistorico (accessed 27 May 2018).

Colombi. A.P.F. (2018) A institucionalização do consenso: atuação da CUT e da FS nos governos do PT (2003-2014). Tese de Doutoramento, Instituto de Economia, Unicamp.

D’Araujo. M.C. (2009) A elite dirigente do governo Lula. Rio de Janeiro: Fundação Getúlio Vargas.

Departamento Intersindical de Estatística e Estudos Socioeconômicos (DIEESE) (2015a) Balanço das negociações dos reajustes salariais de 2014. Série Estudos e Pesquisas, $\mathrm{n}^{\circ} 75$, agosto.

Departamento Intersindical de Estatística e Estudos Socioeconômicos (DIEESE) (2015b) Balanço das greves em 2013. Série Estudos e Pesquisas, n 79, dezembro. https://dieese.org.br/balancodasgreves/2013/ estPesq79balancogreves2013.pdf.

Departamento Intersindical de Estatística e Estudos Socioeconômicos (DIEESE) (2017) Balanço das greves em 2016. Série Estudos e Pesquisas, no 84, agosto.

Instituto Brasileiro de Opinião Pública e Estatística (IBOPE) (2017) Índice de Confiança Social. http://www.ibopeinteligencia.com/produtos-e-servicos/indice-de-confianca-social (accessed 12 April 2017).

Krein, J.D. and M. Biavaschi (2015) Brasil: os movimentos contraditórios da regulação do trabalho dos anos 2000. Cuadernos del Cendes, 32(89): 47-82.

Krein, J.D., A.P. Colombi, P.R. Lemos and H.R. Dias (2017) As reformas regressivas no Brasil e o posicionamento das Centrais Sindicais. Session: Politicas laborales después de la crisis y el giro a la derecha: persisten las diferencias em la región? 2017 LASA Congress, "Dialogues of Knowledge", Lima, Peru, 29 April to 1 May 2017.

Krein, J.D. and H. Dias (2017) Os caminhos do sindicalismo nos anos 2000. Revista Ciências do Trabalho, 8: 117.

Krein, J.D., H. Dias and A.P. Colombi (2015) As centrais sindicais e a dinâmica do emprego. Estudos Avançados, 29(85): 121-35.

Krein, J.D. and M. Manzano (2014) Notas sobre a formalização - Estudo de caso: Brasil. FORLAC/Escritório Regional da OIT para a América Latina e o Caribe.

Melleiro, W. and J. Steinhilber (2016) Brothers in Arms? Trade Union Politics under the Workers Party Governments. In The Political System of Brazil, edited by D. de la Fontaine and T. Stehnken. Berlin: Springer-Verlag.

Pochmann, M., S. Mendonça and S. Barreto (1998) Perspectivas da negociação. São Paulo em Perspectiva, 12(1): n.p.

Schmitter, P.C. and W. Streeck (1999) The Organization of Business Interests: Studying the Associative Action of Business in Advanced Industrial Societies. Discussion Paper 99/1. Max Planck Institute for the 
Study of Societies, Cologne. http://www.mpifg.de/pu/mpifg_dp/dp99-1.pdf (accessed 17 May 2018).

Silver, B. (2003) Forces of Labour: Workers' Movements and Globalization since 1870. Cambridge: Cambridge University Press.

Singer, A. (2012) Os sentidos do lulismo: reforma gradual e pacto conservador. São Paulo: Companhia das Letras.

Wright, E.O. (2000) Working-class Power, Capitalist-class Interests and Class Compromise. The American Journal of Sociology, 105(4): 957-1002.

\section{ABBREVIATIONS AND ACRONYMS}

$\begin{array}{ll}\text { CBDT } & \text { Brazilian Democratic Workers' Central [Central Brasileira Democrática dos } \\ & \text { Trabalhadores] } \\ \text { CDES } & \text { Economic and Social Development Council [Conselho de Desenvolvimento } \\ & \text { Econômico e Social] } \\ \text { CESIT } & \text { Centre for Studies in Trade Unions and Labour Economics [Centro de Estudos } \\ & \text { Sindicais e Economia do Trabalho] } \\ \text { CGT } & \text { General Workers' Trade Union Federation [Central Geral dos Trabalhadores' } \\ \text { CMS } & \text { Confederation of Social Movements [Coordenação dos Movimentos Sociais] } \\ \text { CODEFAT } & \text { Deliberative Council of the Workers' Assurance Fund [Conselho Deliberativo do } \\ & \text { Fundo de Amparo ao Trabalhador] } \\ \text { CRT } & \text { Labour Relations Council [Conselho de Relações do Trabalho } \\ \text { CSB } & \text { Central Brazilian Union [Central dos Sindicatos Brasileiros] } \\ \text { CSP/CONLUTAS } & \text { Central of Trade Unions and Popular Movements [Central Sindical e } \\ & \text { Popular/CONLUTAS] } \\ \text { CSPB } & \text { Unified Central of Public Servants of Brazil [Confederação dos Servidores Públicos } \\ & \text { do Brasil] } \\ \text { CTB } & \text { Brazilian Workers Trade Union Federation [Central dos Trabalhadores e } \\ & \text { Trabalhadoras do Brasil] } \\ \text { CUT } & \text { Unified Workers' Central of Brazil [Central Única dos Trabalhadores] } \\ \text { FNT } & \text { National Labour Forum [Fórum Nacional do Trabalho] } \\ \text { FS } & \text { Union Force [Força Sindical] } \\ \text { ITUC } & \text { International Trade Union Confederation } \\ \text { LGBT } & \text { Lesbian, Gay, Bisexual and Transgender } \\ \text { MTST } & \text { Homeless Workers' Movement [Movimento dos Trabalhadores Sem Teto] } \\ \text { NCST } & \text { New Workers' Union Central [Nova Central Sindical dos Trabalhadores] } \\ \text { PAC } & \text { Growth Acceleration Programme [Programa de Aceleração do Crescimento] } \\ \text { PT } & \text { Workers' Party [Partido dos Trabalhadores] } \\ \text { TUCA } & \text { Trade Union Confederation of the Americas } \\ \text { UGT } & \text { General Workers' Union [União Geral de Trabalhadores] } \\ \text { UNICAMP } & \text { University of Campinas }\end{array}$

\section{BIOGRAPHICAL NOTES}

JOSÉ DARI KREIN is a researcher at the Brazilian Centre for Studies in Trade Unionism and Labour Economics (CESIT) and professor at the Institute of Economics of the University of Campinas (UNICAMP). [Email: darik@unicamp.br]

HUGO DIAS is a researcher at the Centre for Social Studies (CES) at the University of Coimbra and at CESIT. $\mathrm{He}$ is professor at the Institute of Economics of the University of Campinas (UNICAMP). [Email: hugodias@unicamp.br] 